\title{
Retoriek, retoriese analise en prediking
}

\author{
A.B. du Toit \\ Departement Nuwe Testament \\ Fakulteit Teologie (Afd. B) \\ Universiteit van Pretoria \\ PRETORIA
}

\begin{abstract}
In characterising thetoric, its persuasive intent should be highlighted because the persuasive element is true of all three hetorical genera. Graeco-Roman pupils were well-trained in the thetorical ants and it can be accepted that Paul also had a working knowledgc of thetoric. Rhetorical analysis of the New Testament attempts to study the texts of the New Testament in the light of rhetorical features, as developed by the classical theorists and refined by a modern scholar like Perelman. Since the 1970's rhetorical analysis of the New Testament has flourished, although approaches have varied considerably and not all effors were convincing. Nevertheless, it has become clear that the thetorical approach can enrich our understanding of the New Testament, and especially of its letters, considerably. Examples from Romons and Galatians are presented to underscore this point. Since preaching like thetoric, aims at convincing and persuading an audience, hetoric can provide us with imponant stimuli for the praxis of preaching as can be demonstrated from the five prescribed phases of preparing a public specch, as well as from the three modes of persuasion: logas, ethos and pathos.
\end{abstract}

\section{WAT IS RETORIEK EN RETORIESE ANALISE?}

In hierdie artikel word die standpunt beredeneer dat kennis van die retoriek en retoriese analise 'n belangrike bydrae kan lewer tot die bevordering van die gehalte van kerklike prediking. Ons begin met 'n kort kensketsing van die aard en ontwikkeling van die retoriek en retoriese analise.

Retoriek of die 'kuns van welsprekendheid' (ars bene dicendi) word tradisioneel aan die Grieke en Romeine verbind. Die ontwikkeling van die retoriek begin in die sesdevyfde eeu v.C. en vind sy hoogbloei in die tydperk rondom Jesus Christus se optrede. Van die bekendste figure wat hulle daarmee besig gehou het, was Aristoteles, Cicero en Quintilianus, alhoewel daar ook talle ander geskrifte van bekende of onbekende hand oor hierdie onderwerp verskyn het.

Die benaming kuns van welsprekendheid moet nie primèr in estetiese sin verstaan word nie, alhoewel skoonheid van vorm geensins onbelangrik was nie. As van welsprekendheid' gepraat word, gaan dit bo alles om die effektiwiteit van ' $n$ rede in terme van die gestelde doel. Die oorkoepelende doelstelling van alle retoriek was om te oorreed (vgl. Lausberg, 1960:41). Dit is daarom dat Jan Lambrecht retoriek heel kernagtig kan 
beskryf as "the art of persuasive speaking" (1989:240). Om dieselfde rede noem G.A. Kennedy een van sy boeke oor die Griekse retoriek The Art of Persuasion in Greece (Kennedy, 1963).

Hierdie oortuigings- en oorredingsdoel het gegeld vir al drie die genera (Lausberg, 1960:54-55) van die Griekse retoriek:

- Die forensiese genre was, soos die naam aandui, verbind aan die hof en het veral met die kategorieë van skuldig en onskuldig gewerk. Hierdie genre was daarop gerig om deur middel van 'n effektiewe aanbieding 'n positiewe of negatiewe hofbeslissing te bewerk, en is, vanuit 'n tydperspektief gesien, met die verlede verbind.

- Die deliberatiewe genre was tuis op die openbare verhoog, byvoorbeeld by politieke debatvoering, en was veral op die toekoms gerig. Hierdie genre het hoofsaaklik met die kategorieë van voordelig of nadelig gewerk, en het die uitsluitlike doel gehad om 'n bepaalde publieke aksie te bevorder of teen te werk.

- Die demonstratiewe of epideiktiese genre was veral by feestelike geleenthede aan die orde en het met die lof (=mooi, goed) en blaam (=lelik, sleg) van byvoorbeeld openbare figure se dade, die stad of die vaderland gewerk. Vergelykenderwys was hierdie genre die minste op oorreding ingestel. Tog het die aanprysing of afwysing van bepaalde houdings en optredes 'n beïnvloedende krag besit en is die publiek aangemoedig om hulle met sekere waardes te assosieer en van ander te distansieer. Hierdie aspek van die retoriek is deur onder meer Perelman en OlbrechtsTyceta (1969) verder uitgebou. Langs hierdie weg word retoriek 'n metode om die gehoor se aanvaarding of afwysing van sekere waardes te versterk (Watson, 1991:116).

Dit sou egter heeltemal foutief wees om te meen dat die drie genera beperk was tot die drie bogenoemde situasies wat as hulle oorspronklike Sitz im Leben beskou is. Hulle is in talle ander omstandighede en met inkorporering van mekaar se tipiese elemente aangewend (Lausberg, 1960:61; Mack, 1990:34-35).

Die Grieks-Romeinse jeug is op sekondêre skoolvlak (vanaf vyftien) deeglik in die retoriek onderrig en moes nie net leer hoe om 'n toespraak voor te berei nie, maar het die regte lewering daarvan prakties ingeoefen. Hoër opvoeding (vanaf agtien) aan die skole vir retoriek het jongmense vir talle professies toegerus. Om deel te hê aan die Hellenistiese kultuur was sinoniem met die vermoë om minstens 'n geoefende oor te hê vir die velerlei manifestasievorme van die retorika (Mack, 1990:30-31). Om goeie retoriek te beoefen en te onderskei was veel meer as om mooi stylfigure aan te wend of te onderskei. Dit het ook en veral gegaan om die logika, om dialektiese vermoëns, om die kwaliteit van argumentasie. Die vyf stappe wat leerlinge en studente moes bemeester en wat as voorgeskrewe basis vir die voorbereiding van toesprake gedien 
het, was die volgende (kyk ook die goeie tipering by Lambrecht, 1989:140-141):

* Die inventio (die vind-, ontdek-handeling) was die stadium van materiaalversameling. Vir 'n hofgeding moes byvoorbeeld alle relevante bewysmateriaal en argumente gevind word. Die term soek word tipies van hierdie stadium.

* Die dispositio (rangskikking, ordening) was die stadium waarop die materiaal gerangskik is in 'n goed-georganiseerde geheel wat noukeurige beplanning gevra het. Die verskillende dele (partes) van 'n rede was die prooemium (=exordium: inleiding, voorwoord), die narratio (vertelling), die probatio (=confirmatio: respektiewelik bewys, bevestiging), die refutatio (weerlegging), die peroratio (=epilogus: afsluiting, epiloog). Elemente soos die propositio (stelling, tema), kon egter net na die narratio volg, terwyl die probatio en die refutatio saam as die angumentatio (bewysvoering, beredenering) kon funksioneer (Lausberg, 1960:148149).

* Die elocutio (gestaltegewing) was die fase waarop besluit is op die regte inkleding van die aanbieding: styl, woordkeuse, stylfigure, ensomeer.

- Met die memoria (memorisering) is die hele toespraak of 'n raamwerk daarvan in die geheue vasgelê.

- Die pronuntiatio (uitspreek, aanbieding), was die finale fase. Dit het te doen gehad met die kuns van die lewering van die toespraak as sodanig: stemmodulasie, gesigsuitdrukking, gebare.

Die studie van die retoriek het deur alle eeue aandag gekry; dit was deel van die kulturele toerusting van elkeen wat die Klassieke bestudeer het. Beroemde predikers in die kerkgeskiedenis het in meerdere of mindere mate van die kuns van die retoriek gebruik gemaak. Augustinus wy byvoorbeeld boek 4 van sy De doctrina christiana aan die Bybelse en vroeg-Christelike retoriek. Die studie van die retoriek het in die Bybelwetenskap redelik sterk aandag ontvang gedurende en veral teen die einde van die negentiende eeu en in die eerste dekade van die twintigste eeu. Prominente name in hierdie verband is Heinrici (1887), Johannes Weiss (1897), König (1900), Norden (1913) en Bultmann (1910).

Hierna is die studie van die retoriek in die Bybelwetenskap vir 'n halfeeu afgeskeep, waarskynlik omdat opwindende nuwe benaderings soos die Formgeschichte en die Redaktionsgeschichte die aandag opgeëis het. In sy beroemdgeworde presidensiële toespraak voor die Society of Biblical Literature in 1968 het J. Muilenburg egter weer aandag vir die retoriek opgeëis. In hierdie selfde tyd het ook die werk van Perelman gehelp om die fokus weer eens op die retoriek te plaas. Van sy werk word gepraat as "the new rhetoric" (Perelman \& Olbrechts-Tyceta, 1969). Hierna het die toepassing 
van die retoriese analise op die veld van die Nuwe Testament 'n ware ontploffing beleef (vgl. punt 3).

Retoriese analise ten opsigte van die Bybelwetenskap wil die Bybelteks en sy performatiewe aspekte (vgl. punt 2) analiseer in die lig van die insigte en voorskrifte van die retoriek. Die toepaslikheid van die retoriese analise hang nie uitsluitlik van die vraag af of die Bybelskrywers die antieke retorika self geken en doelbewus beoefen het nie (Classen, 1991:2-3), aangesien die Grieks-Romeinse retoriek in baie opsigte sekere basiese beginsels raakgesien het wat eie is aan alle menslike oorredingskuns. Die retoriek verleen aan ons 'n verrykende insig in die werking van die kuns van oorreding in die algemeen, selfs in daardie gevalle waar die voorskrifte van die antieke retoriek nie bekend of doelbewus in ag geneem was nie. Aangesien die Bybelskrywers 'n bepaalde oortuiging en saak het wat hulle aan hulle lesers wil 'verkoop', en die meeste Bybelse dokumente dus 'n oorredende oogmerk het, is daar dieperliggende lyne wat daardie Bybelboeke en die retoriek, by alle verskille, tog aan mekaar verbind. Uiteraard word die toepaslikheid van die retoriese analise egter nog groter waar die dokumente self 'n mate van kennis van die Grieks-Romeinse retoriek vertoon.

\section{DIE RETORIESE BENADERING AS EEN MANIFESTASIE VAN DIE PRAGMATIESE BENADERING TOT TEKSSTUDIE}

Vir baie lank is in die eksegese gekonsentreer op die inhoudelike of die informatiewe aspek. Dit het gegaan om die inligting wat meegedeel word, en dan in besonder om die teologiese inligting. In terme van die kommunikasiemodel met sy vier pole en die boodskap as die sentrum waaromheen hierdie vier pole funksioneer, het die hoofklem op die sender en die boodskap geval en nie so sterk op die ontvanger nie. Met die pragmatiek van tekste gaan dit nie om die informatiewe nie, maar om die performatiewe, met ander woorde om wat die teks wil presteer in terme van die effek wat die teks op die ontvanger het. Daarom val die klem hier veel sterker op die ontvanger. Om 'n sekere resultaat by die ontvanger te bewerkstellig, manipuleer die sender sy teks om die beoogde resultaat by die ontvanger te bewerk. Vir hierdie doel moet hy die ingesteldheid, die eie aard en die omstandighede van sy ontvangers op besondere wyse in ag neem. Elkeen van die drie benaderings wat vandag op die pragmatiek van tekste konsentreer, naamlik die resepsie-analise, die taalhandelingteorie en die retoriese analise, dra op sy eie wyse by tot die beter verstaan van die tekspragmatiek. Metodologies is dit nuttig om eklekties van al drie hierdie benaderings gebruik te maak, omdat elkeen sy eie winspunte het - mits die navorser goed weet wat hy doen!

\section{DIE RETORIESE ANALISE EN DIE PAULINIESE GESKRIFTE}

Die toepassing van retoriese analise op die Nuwe Testament het 'n besondere stoot gekry met die werk van H.D. Betz en W. Wuellner ('n geannoteerde lys van albei se publikasies is te vind by Powell, 1992). Veral eersgenoemde se Galate-kommentaar het in hierdie verband 'n groot stimulus gelewer. Alhoewel die retoriese analise van die Nuwe Testament in baie opsigte nog in sy kinderskoene staan, is reeds baie belang- 
rike werk in hierdie verband gedoen en ons insigte in veral die Nuwe-Testamentiese briefliteratuur word elke dag meer verryk. Afgesien van die werke van Betz en Wuellner het ook persone soos Kennedy, Schneider, Scroggs, Stowers, Jewett, Bünker, Siegert, Hughes, Johanson, Hester, Forbes, Watson, Kraftchick, Mack, Robbins en vele andere reeds bydraes gelewer (oorsigte by Hughes, 1989; Mack, 1990; vgl. ook die nuttige en uitvoerige bibliografie van Powell 1992 - wat egter wyer gaan as die retoriese kritiek). In ons eie geledere het onder meer A.H. Snyman (1984), J.N. Vorster (1991) en J. Botha (1991:166-240) substansiële bydraes gelewer.

Die oorkoepelende benaming retoriese analise van die Nuwe Testament huisves 'n menigte uiteenlopende benaderings. Gelukkig vertoon heelwat van hierdie werk meer diepgang as ouer studies. Waar laasgenoemde dikwels bloot op die stilistiek en by name op stylfigure gekonsentreer het, gaan dit nou veel meer om die analise van effektiewe argumentasie.

Soos dit nou maar eenmaal gaan met belangrike ontdekkings en herontdekkings, het ook nie alle beoefenaars van die retoriese analise aan die versoeking ontsnap om die waarde van die retoriek vir die studie van die Nuwe Testament te oorspan nie. Dit blyk nêrens duidelike $r$ as by die bepaling van die aard en indeling van die NuweTestamentiese briewe nie. Betz byvoorbeeld het besluit dat die Galatebrief tot die forensiese genre behoort en die hele Galatebrief volgens die retoriese skema gaan indeel. Ander weer was van oortuiging dat hierdie brief tot die deliberatiewe genre behoort en hulle hantering van Galate het dienooreenkomstig van dié van Betz verskil (Du Toit, 1990:156-158). Dieselfde proses is by die ander Paulusbriewe aan die gang. Jewett wil Romeine in 'n streng retoriese keurslyf indruk (kyk Du Toit, 1989:195). Hughes (1989) doen dieselfde met 2 Tessalonisense. In hierdie proses word allerlei akrobatiese toere onderneem en word die Bybelteks in skemas ingeforseer waarin dit nie hoort nie.

Veral twee sake kom hier ter sprake. Eerstens moet ons vra of Paulus met die Griekse retoriek bekend was, en tweedens, indien ons 'n direkte of selfs 'n indirekte kennis van die retoriek by hom aanvaar, wat die verhouding van retoriek tot epistolografie in die Pauliniese geskrifte is.

Wat eersgenoemde vraag betref, moet ons aanvaar dat Paulus op skool (in Tarsus of later?) minstens 'n basiese kennis van die Grieks-Romeinse retoriek moes opgedoen het. Die Helleniseringsproses was in Paulus se tyd selfs in Palestina ver gevorder (kyk bv. Mack, 1990:29). Ook in Jerusalem moes minstens 'n gepopulariseerde weergawe van retoriese beginsels bekend gewees het. Paulus se kennis van die Grieks-Romeinse retoriek blyk dan ook duidelik uit bepaalde elemente in sy veelsydige korrespondensie.

Paulus se kennis van die retoriek beteken egter nie dat die retoriese voorskrifte die hantering van sy briewe gaan oorheers het nie. Hy het ook van ander tradisies gebruik 
gemaak. Sy geskrifte eerbiedig in heel eerste instansie die genre van die Griekse brief, alhoewel hy dit op sy eie unieke wyse aanpas. Daarom is dit verkeerd om sy briewe in een van die drie retoriese genera in te forseer. Die futiliteit van sulke pogings blyk eerstens uit die feit dat tipiese elemente uit die drie retoriese genera vermeng kon word; tweedens blyk dit daaruit dat die onderskeid tussen hierdie drie genera reeds destyds omstrede was (Lausberg, 1960:56); en derdens blyk dit uit die groot verskille tussen die onderskeie moderne geleerdes. Ons kan met veel beter gronde aanvaar dat Paulus die antieke briefskema as basis neem, maar binne die nuimte van hierdie skema in vele opsigte van die insigte en die tegnieke van die Griekse retoriek gebruik maak.

\section{ENKELE VOORBEELDE VAN DIE BELANG VAN DIE RETORIESE ANALISE VIR DIE VERSTAAN VAN DIE NUWE TESTAMENT}

Om die belang van die retoriese analise vir die verstaan van die Nuwe Testament te verduidelik, gaan ek slegs 'n paar voorbeelde uit die Romeinebrief en uit Galasiërs neem.

Volgens die klassieke retoriek beheers drie wyses van oorreding die kunkrete aanbieding van 'n rede: ethos, pathos en logos (Aristoteles; vgl. ook Lambrecht, 1989:240).

Die ethos het te make met die positiewe beeld wat die hoorders van die redenaar het: sy kwaliteit en sy karakter, en hierdie oorredingswyse word gewoonlik aan die begin van ' $n$ rede aangewend. Die pathos het te make met die appèl op die hoorders se emosies. Dit tree gewoonlik op 'n later fase na vore, veral aan die einde van 'n rede. Die logos dui op die helder logika van die diskoers, wat die gehoor deur middel van induktiewe of deduktiewe argumente tot insig moet bring (Lambrecht, 1989: idem).

Wat ethos betref, is dit duidelik dat Paulus in Romeine, soos trouens ook in sy ander briewe, doelbewus 'n positiewe beeld van homself as spreker/skrywer wil projekteer. Dit word gedoen om 'n "Affekt-Brücke" (Lausberg, 1960:141) tussen hom en sy hoorders te skep. Soos ons reeds gesien het, speel die kwaliteite en aard van die spreker hier ' $n$ belangrike rol. Wat egter net so belangrik is, is dat die spreker sy besondere gehoor in ag moet neem. Dit gaan dus in die skep van 'n ethos om 'n geslaagde 'huwelik' tussen die kwaliteite van die spreker en die situasie van die lesers, of, beter gestel, daarom dat die skrywer sy persoon en hoedanighede so sal aanbied dat dit positief deur die hoorders, in hulle omstandighede, ervaar sal word. 'n Aandagtige deurwerk van die kenmerke van die eerste sewentien verse van Romeine toon onmiskenbaar hoe Paulus, deur middel van die skep van 'n ethos, 'n positiewe band tussen hom en sy lesers/hoorders lè: Die klem op gemeenskaplike outoritatiewe simbole, op sy dienaar-wees, op sy apostelskap as genadevoorreg, die danksegging, die beklemtoning van sy jarelange begeerte om hulle te besoek, die innuendo aangaande die weldoenersrol wat hy gaan speel - al hierdie elemente en nog veel meer (kyk Du Toit, 1989) - beklemtoon dat Paulus hier doelbewus besig is om 'n ethos tot stand te bring by 'n aantal Christenhuisgemeentes aan wie hy relatief onbekend is en wie hy tot same- 
werking in evangeliediens wil oorreed. Opvallend is egter dat hy hierdie Christene in die dankseggingsgedeelte geensins buite alle verhouding tot wat hy van hulle weet, prys nie. Hy moet die kriterium van die sinceritas, wat die korrelasie tussen res en verba respekteer, in ag neem. Afgesien van talle ander retoriese elemente in Romeine, noem ek nog net die voorkoms van retoriese figure soos enthumeme (bv. 1:5-6), correctio (1:12), litotes (1:13 en 16), hiperbool (1:8), klimaks (8:3) onder vele meer (i.s. Rom. 8:31-39 vergelyk byvoorbeeld Snyman, 1984).

Net soos Romeine bevat die Galatebrief talle voorbeelde van die invloed van die Grieks-Romeinse retoriek. Alhoewel Betz (1979) en selfs Longenecker (1990) in hierdie verband versigtig gehanteer moet word, blyk die voordele van die retoriese benadering in verskeie opsigte in hierdie twee kommentare. Van my kant word slegs enkele gesigspunte bygebring. Ten opsigte van die drie oorredingswyses van ethos, pathos en logos, kan sonder moeite aangetoon word dat al drie in Galasiërs funksioneer. Al is Galasiërs as gevolg van Paulus se duidelike ontsteltenis oor die invloed van die dwaalleraars, 'n redelik emosionele brief, is dit geensins sonder logos nie. Die vereiste tot logiese beredenering volg Paulus in Galasiërs 1:11-4:11 (Du Toit, 1990;1991). Met twee logiese argumente kom hy om sy lesers van die korrektheid van sy evangelie te oortuig. Eers verduidelik hy aan hulle dat hy sy evangelie van God self by wyse van ' $n$ openbaring ontvang en dit deurgaans in verskillende episodes van sy bediening gehandhaaf het (1:11-2:21). Daarna wys hy sy lesers daarop dat dit juis op grond van die prediking van die evangelie van die regverdiging uit die geloof was dat hulle die Heilige Gees en sy werkinge beleef het (3:1-4:11). Terselfdertyd het hy in die eerste deel van sy brief sy ethos beklemtoon. Ironies genoeg geskied dit hierdie keer, anders as in Romeine, juis deur sy ware apostelskap te beklemtoon en 'n dankseggingsgedeelte weg te laat. So 'n danksegging sou op hierdie stadium, waar hy op die punt staan om die Galasiërs se dreigende afvalligheid te gesel, ongeloofwaardig deurkom en sy ethos juis benadeel. Na die eerste tien verse gaan hy egter doelbewus voort om sy ethos verder te bou as iemand wat sy evangelie van God ontvang het en nie van mense nie (Gal. 1:11-2:21). Na hierdie klem op ethos en logos gaan Paulus in 4:12 egter oor na pathos. Nou doen hy 'n beroep op die Galasiërs se emosies. Hy herinner hulle aan hulle vroeëre welwillendheid teenoor hom en hy pleit by hulle soos 'n moeder wat opnuut in barensnood is oor haar kinders (vgl. v.19).

Nog 'n voorbeeld: Die retorici het aanbeveel dat 'n spreker sy opponente se optrede en karakter op allerlei maniere in donker kleure moet skilder. Hierdie proses word vituperatio genoem. Paulus doen presies dit in Galasiërs. Hy skilder die dwaalleraars as mense wat die gemeentes van Galasië verwar $(1: 7 ; 5: 8)$, wat God se vloek verdien (1:9), towenaars (3:1), eie-gewinsoekers (6:12-13), ensovoorts. Daarteenoor moes 'n mens jou gehoor prys (=laudatio) om hulle aan jou kant te kry. Dit doen Paulus in Galasiërs 4:12 e.v.

Ek noem slegs nog een voorbeeld: In 6:17 vertel Paulus dat hy die stigmata tou lesou in 
sy liggaam omdra. Hierdie uitspraak was in die konteks altyd ietwat bevreemdend. Betz wys egter daarop dat 'n redenaar, om die integriteit van sy kliënt te bewys, byvoorbeeld die wondmerke wat hy in gevegte vir sy vaderland opgedoen het, fisies aan die hof kon uitwys (Betz, 1979:323). Hierdie vertoning moes 'n geweldige emosionele appèl op die jurie gemaak het. Op dieselfde manier wys Paulus nou op sy eie 'oorlogswonde' vir Christus wat hy in sy bediening opgedoen het. Hoe sou die Galasiese Christene nog langer kon weier om hom gelyk te gee?

Op hierdie trant sou nog lank voortgegaan kon word. Uit die Korintiërbriewe sou byvoorbeeld 'n rykdom van retoriese insigte gehaal kon word. Die bostaande voorbeelde behoort egter reeds 'n aanduiding te gee van die waarde van retoriese analise vir die beter verstaan van die Nuwe-Testamentiese dokumente.

Dit is nie die bedoeling en plek om hier in te gaan op die belang van die retoriese analise vir die praktyk van ons eksegetiese arbeid nie. Dit sou reeds enigsins by implikasie duidelik begin word het uit die onmiddellik voorafgaande bespreking. Nietemin word hier twee gesigspunte uitgelig: Eerstens sal die eksegeet vocrtaan in gedagte moet hou dat die Bybelteks nie bloot op sy informatiewe of inhoudelike vlak beluister moet word nie, maar ook op sy pragmatiese vlak, met ander woorde dit moet nie net gaan om die vraag na wat die teks 'sề' nie, maar ook om wat die teks 'wil laat gebeur'. Tweedens moet die ontdekking van hierdie tweede, performatiewe dimensie die eksegeet weerhou van 'n 'oorlading' of 'n 'oor-interpretasie' van die teksinhoud. Wanneer 'n skrywer byvoorbeeld die dwaalleraars met geweldige sterk negatiewe terme afmaak, is sy primère bedoeling nie om objektiewe feitelike inligting deur te gee nie, maar om sy geweldige afkeuring van hierdie mense se lering en optrede so te verwoord dat sy lesers in hierdie negatiewe reaksie betrek word. Wanneer Paulus die Judaiserende opposisie byvoorbeeld "honde" noem (Filip. 3:2), lê hierdie tipering suiwer op die retoriese vlak. 'n Tweede voorbeeld: retoriek het 'n voorkeur vir hiperboliese taalgebruik. As Paulus in Romeine 1:8 God daarvoor dank dat die Romeinse Christene se "geloof in die hele wêreld verkondig word" (letterlike vertaling), maak hy heel waarskynlik van so 'n hiperbool gebruik. Dit sou foutief wees om "die hele wêreld" letterlik te vertolk. Heel waarskynlik wil hy 'inhoudelik' nie meer sê as dat daar 'wyd en syd' daarvan gepraat word dat daar ook in Rome nou Christene is nie.

\section{RETORIEK, RETORIESE ANALISE EN DIE PREDIKING}

\section{S.1 Inleidend}

Die Praktiese Teologie, en by name die Homiletiek, bestee reeds geruime tyd aandag aan die retoriek. Veral Otto $(1981 ; 1982 ; 1986 ; 1987)$, Josuttis (1985) en Zerfass (1987) verdien hier vermelding. Ook Long (1989) en Dingemans (1991) se name moet hier uitgelig word. En nader aan huis het Vos (1992) onlangs met nadruk die belang van die pragmatiese benadering, veral dié van die taalhandelingteorie, vir die prediking aan die orde gestel. 
Soos in die Bybelwetenskap, bestaan daar ook in die Praktiese Teologie ernstige probleme rondom die gebruik van die term retories. Die onderskeiding tussen retoriek en stilistiek is byvoorbeeld in sekere opsigte problematies. Belangriker in hierdie verband is egter die verhouding tussen retoriek en pragmatiek. By Long (1989:25-29) is hierdie terme volkome uitruilbaar. Gemelde 'ruim' aanwending van die term retories is begryplik, aangesien die retoriek sterk op die pragmatiese of performatiewe dimensie van kommunikasie toegespits is. Daar bestaan egter ook ander leser-georiënteerde benaderings soos die taalhandelingteorie en die resepsiekritiek. Dit sou dus terminologies suiwerder wees om die term retories te reserveer vir die tradisionele 'kuns van welsprekendheid', soos dit vanuit die Klassieke teorie ontwikkel het, en terme soos pragmaties en performatief te gebruik wanneer die totale performatiewe dimensie van taal onder die loep geneem word.

In die bogenoemde werke is nog relatief min gedoen om die waarde van die retoriek vir die praktyk van die prediking te ondersoek. Die neiging by die eersgenoemde twee Duitse skrywers is om die term retories as 'n soort teoretiese vertrekpunt te neem, sonder om konkreet op die kenmerke van die retoriek in te gaan. Waar dit egter wel gedoen word, versand die diskussie weer te maklik in 'n poging om die prediking in een van die retoriese genera in te deel, soos by Zerfass $(1987: 34-41 ; 104-110)$ en, in geringer mate, ook by Dingemans (1991:159-163). Presies dieselfde tendens het na vore getree in die onvrugbare stryd om die retoriese klassifikasie en indeling van die Paulusbriewe (Du Toit, 1989:194-196; 1990:156-158). Waarom moet die Paulusbriewe, waarom moet die Christelike prediking opsluit in een van die drie retoriese genera inpas? En wat wil ons met so 'n kunsmatige klassifisering bereik? Dit sou wetenskaplik veel meer verantwoord wees om die eie aard van die Christelike prediking te honoreer, vervolgens te vra in watter opsigte dit met die retoriek oorvleuel, en uiteindelik, met respektering van albei se spesifiek eie, te vra hoe die retoriek die Christelike prediking kan verryk. In wat volg, wil ek dit waag om enkele sodanige (na my mening) verrykende insigte aan te stip. Ek is deeglik bewus van die feit dat ek geen praktiese teoloog is nie en dat ek bloot aan die oppervlak van moontlikhede raak.

\section{$5.2 \quad$ Negatiewe gesigspunte}

Vooraf moet drie caveats aangeteken word. Eerstens moet daar nie na die retoriese analise as 'n soort towerlampie gegryp word wat kwansuis alle homiletiese probleme gaan oplos nie. Die waarde van die retoriek in hierdie verband is aansienlik, maar nogtans beperk. Tweedens moet die homiletiek waak teen 'n terugval in retoriese tegnieke en voorskrifte (vgl. Otto, 1986:55-56). Hierdie onoordeelkundige navolging van die retoriek het die prediking vir baie eeue in sy ban gehou. Selfs 'n skeppende, vrye gees soos Luther, met sy klem op Christus en die evangelie, was nog in sekere opsigte aan die retoriese voorskrifte gebonde (Otto, 1986:71-73). En derdens mag die benutting van die retoriek nie uitloop op 'n beklemtoning van vorm ten koste van inhoud nie. Mooi taalgebruik, treffende beelde, sprekende gebare mag nooit meer wees as beskeie transparante vir die evangelie-inhoud nie. Sodra hierdie dinge 
fokuspunt op sigself word, word hulle struikelblokke. Dan verander die 'kuns van welspekendheid' in die 'kuns van mooi-sprekendheid' en kom die inherente krag van die evangelie, sowel as die egtheid en innerlike oortuiging van die prediker, in gedrang.

\subsection{Positiewe gesigspunte}

Vervolgens nou enkele positiewe gesigpunte. Hierdie positiewe gesigspunte vloei voort uit die feit dat daar, afgesien van belangrike, voor die hand liggende verskille, tog twee basiese ooreenkomste tussen retoriek en prediking bestaan: eerstens gaan dit in albei gevalle om 'n belangrike openbare optrede waarby 'n enkele spreker hom deur middel van 'n rede tot 'n gehoor rig. Tweedens wil die spreker in albei gevalle sy gehoor so sterk as moontlik oorreed. In die lig hiervan kan ons verwag dat 'n deeglike kennis van die retoriek en van die insigte van die retoriese analise die prediking in meer as een opsig kan verryk.

\subsubsection{Retoriese analise open 'n ander kommunikasie-dimensie}

Die waarde van die retoriese analise vir die prediking lê allereers daarin dă hierdie metode aan ons 'n dieper insig gee in die aard en betekenis van die Bybelteks sowel as ons eie prediking. Saam met die ander metodes wat op die pragmatiek van tekste konsentreer, het die retoriese analise ons 'n totaal ander dimensie van kommunikasie laat ontdek, 'n dimensie wat vir baie jare verwaarloos was. Ons oë is naamlik geopen vir die feit dat die Nuwe-Testamentiese tekste, elkeen op sy eie wyse, oorredend van aard is (vgl. hierbo). Daarom skryf byvoorbeeld Kennedy (1984:3) in hierdie verband: "The writers of the New Testament had a message to convey and sought to persuade an audience to believe it, or to believe it more profoundly." Die Nuwe-Testamentiese tekste is pastoraal-pragmatiese dokumente wat in wese presies dieselfde beoog as wat die prediking behoort te beoog. Om te sê dat ook ons prediking oorredend van aard moet wees, is om te sê dat daar, deur middel van ons prediking, en onder die werking van die Heilige Gees, iets met ons hoorders moet gebeur. Hulle moet oortuig word, 'n keuse maak, deur die Gees en die woord van die prediking verander word. Daarom moet die prediking doelgerig toegespits word op daardie 'veranderingsproses', en alle teologies verantwoorde middele aanwend om dit te bevorder en te bestendig. Geen preek is deeglik voorberei voordat die prediker homself duidelik van sy doelwitte vergewis het en tevrede is dat die preek genoegsaam afgestem is op die oortuigings- en oorredingsaspek deur middel waarvan hierdie doelwitte bereik moet word. Die preek moet dus 'n gerigtheid, 'n vaartbelyndheid besit wat afpyl op die doel, en al oorredende die hoorders meeneem onderweg na daardie doel.

\subsubsection{Preekvoorbereiding as selfdissipline}

Wat die voorbereiding van die preek betref, is daar sekerlik veel wat ons van die retorika kan leer. Daarmee word geensins bedoel dat die preek, soos vroeër wel gebeur het, op die retoriese model geskoei moet word nie. Wat egter wel belangrik is, is dat daar sekere basiese insigte aan die retoriek ten grondslag lê wat ons nie kan 
bekostig om te ignoreer nie. Die volgende gesigspunte tree hier na vore:

Die beofening van die retoriek vra van die redenaar 'n geweldige selfdissipline ten opsigte van sy voorbereiding. Waar die prediking met so 'n geweldige saak soos die koninkryk van God te make het, mag hierdie selfdissipline, om dit sag te stel, geensins agterweë bly nie.

Die vyf fases van die voorbereiding van 'n rede bevat vir die prediker in sy preekvoorbereiding uiters belangrike riglyne:

* Die inventio-fase waarin die materiaal versamel word, wys hoe noodsaaklik hierdie aspek is. 'n Prediker skud sy preekinhoud nie so sito-sito uit sy mou nie. Afgesien van die Bybelteks en die basiese eksegetiese hulpmiddels, moet die leraar wyd lees: artikels, koerante, tydskrifte, goeie boeke. Hy moet onder sy mense beweeg. Alleen so sal hy relevant kan bly. En voortdurend moet sy oë oop wees vir moontlike preekmateriaal: 'n preekidee, 'n treffende beeld, 'n kort, toepaslike verhaal, 'n aangrypende gedig, gedagtes van bekende predikers uit die verlede en die hede, 'n aktuele koerantberig. Hierdie is middele wat die spykers diep inslaan. Dit werk net eenvoudig nie om op die vooraand van 'n erediens daardie materiaal te gaan soek nie. Dan is daardie koerantberig al klaar weggegooi, die gedig kruip weg. Daarom moet hierdie materiaal deurlopend versamel en sistematies bewaar word.

* Die dispositio-fase, waarin die diskoers logies en helder georden word, mag nie oorgeslaan word nie. Vir die memoriseer van die preekinhoud, sy verstaanbaarheid en sy latere 'terug-roepbaarheid' is dit absoluut noodsaaklik dat 'n preek goed gestruktureer moet wees en logos moet besit. Daarom moet 'n leraar baie tyd vir sy preekstrukturering neem. En hiervoor is deeglike, rustige meditasie nodig.

* Die elocutio-stadium is dié een waarin die diskoers daadwerklik verwoord word. Hier moet spesiale aandag gegee word aan woordkeuse, treffende beelde, voorbeelde ensomeer. Verouderde preektaal moet aan die een kant vermy word, maar aan die ander kant ook die moderne slang. Die prediker moet eietyds wees, sonder om platvloers te wees. Iets van die besef dat hy saam met die gemeente in God se teenwoordigheid staan, moet ook in die prediker se taalgebruik deurkom.

* Die memoria-fase word dikwels afgeskeep. Daarom het baie predikers Sondae hulle koppe in die preek, in plaas van die preek in hulle koppe. Niks verbreek kommunikasie soveel as hierdie soort manuskripgebondenheid nie.

* Ook die pronuntiatio-fase, waar aan die lewering self aandag gegee word, mag nie afgeskeep word nie. Veral die hoorbaarheid van elke woord en sinvolle gebare moet aandag kry. Die leraar moet steeds bedag wees op die rampspoedigheid van 
'n preekstem. Natuurlikheid, egtheid, belewing is wat gevra word.

\subsubsection{Ethos en patos}

Ten slotte nog iets oor die ethos en die pathos. Ons het gesien dat die ethos te make het met die wyse waarin die spreker daarin slaag om positief oor te kom na sy hoorders en 'n $A f f e k t$-Brücke te skep. Dit is nodig dat elke prediker telkens 'n evaluasie sal laat doen van hoe hy oorkom na die gemeente. Bestaan daar inderdaad by die gemeente ' $n$ openheid en gewilligheid om na hom te luister? Is daar gesindhede en houdings wat pla? Het hy hinderlike gewoontes op die kansel? Is hy werklik solidêr met sy mense? Niks skep so 'n stewige ethos as liefde, nederigheid en egtheid nie.

Opvallend genoeg was daar in die Grieks-Romeinse rede egter ook plek vir die pathos. Predikers wat die kuns verstaan om mense se trane te trek, skep 'n vlak vroomheid. Die vraag is egter of baie preke uit reaksie teen 'n te sterk gevoelsbeklemtoning nie vandag weer te serebraal geword het nie. Die verstand word betrek, maar die hart word koud gelaat. Terwyl ons moet oppas dat die pendulum nie nou weer na die ander kant toe deurswaai nie, moet ons prediking tog paslike voorsiening vir die beleweniselement en vir die emosionele aspek maak. Die hart van ons jongmense, maar ook van die hoogsgeleerde moderne wetenskaplike mens, beleef op hierdie vlak 'n geweldige behoefte.

\section{BIBLIOGRAFIE}

BETZ, H.D. 1979. Galatians. A Commentary on Paul's Letter to the Churches in Galatia. Philadelphia : Fortress Press. (Hermeneia.)

BOTHA, J. 1991. Reading Romans 13. Aspects of the Ethics of Interpretation in a Controversial Text. Stellenbosch. (Unpublished doctoral thesis.)

BUltmanN, R. 1910. Der Stil der paulinischen Predigt und die kynisch-stoische Diatribc. Vandenhoeck \& Ruprecht. (Forschungen zur Religion und Literatur des Alten und Neuen Testaments 13.)

CLASSEN, CJ. 1991. Paulus und die antike Rhctorik. Zeitschnift für die neutestamentliche Wissenschät und die Kunde der alteren Kirche, 82:1-33.

DINGEMANS, G.D.J. 1991. Als Hoorder onder de Hoorders. Hermeneutische Homiletiek. Kampen : J.H. Kok.

DU TOIT, A.B. 1989. Persuasion in Romans I:1-17. Biblische Zeitschrift, 13:193-209.

DU TOIT, A.B. 1990. Analise van die opbou, argumentasiegang en pragmatiek van die Galatebrief: 'n Eerste orientering. Skrif en Kerk, 11:155-165.

DU TOIT, A.B. 1991. Analise van dic opbou, argumentasiegang en pragmatiek van die Galatebrief: 'n meer gedetaillecrde oorsig. Skrif en Kerk, 12:214-241.

HEINRICl, C.F.G. 1887. Das zweite Sendschreiben des Apostels Paulus an die Korinther. Berlin : Hertz.

HUGHES, F.W. 1989. Early Christian Rhetoric and 2 Thessalonians. Sheffield : JSOT Press. (Journal for the Study of the New Testament Supplement Series 30.)

JOSUTTIS, M. 1985. Rhetorik und Theologie in der Predigtarbeit. Homiletische Studien. Mũnchen : Chr. Kaiser Verlag.

KENNEDY, GA. 1963. The Art of Persuasion in Greece. Princeton : Princeton University Press.

KENNEDY, G.A. 1984. New Testament Interpretation through Rhetorical Criticism. Chapel Hill \& London : North Carolina Press.

KöNIG, E. 1900. Stilistik, Rhetorik, Poetik in Berug auf die Biblische Literatur. Leipzig : Weicher. 
LAMBRECHT, J. 1989. Rhelorical Criticism and the Ncw Testament. Tijdschrift voor Filosofie en Theologie, 50:239-253.

LAUSBERG, H. 1960. Handbuch der litcrarischen Rhctorik. Eine Grundlegung der Literaturwissenschaft. München : Max Hueber.

LONG, T.G. 1989. Preaching and the Literary Forms of the Bible. Philadelphia : Fortress Press.

LONGENECKER, R.N. 1990. Galatians. Dallas: Word Books, Publisher. (Word Biblical Commentary.)

MACK, B.L. 1990. Rhetoric and the New Testament. Minneapolis : Fortress Press. (Guides to Biblical Scholarship.)

NORDEN, E. 1913. Die antike Kunstprosa vom VI. Jahrhundert vor Christus bis in dic Zeit der Renaissance. Stuttgart : B.G. Teubner.

OTTO, G. 1981. Rhetorisch Predigen. Wahrheit als Mitteilung. Beispiele zur Predigtpraxis. Gütersloh: Gütersloher Verlagshaus Gerd Mohn.

OTTO, G. 1982. Wie entsteht eine Predigt? Ein Kapitel praktischer Rhetorik. München : Chr. Kaiser Verlag.

OTTO, G. 1986. Praktische Theologic 1: Grundlegung der Praktischen Theologie. Munchen : Chr. Kaiser Verlag.

OTT(, G. 1987. Predigt als rhetorische Aufgabe. Homiletische Perspektiven. Neukirchen-Vluyn : Ncukirchener Verlag.

PERELMAN, Ch \& Olbrechts-Tyceta, L. 1969. The New Rhetoric. A Treatise on Argumentation. Notre Dame, Ind. : University of Notre Damc Press.

POWELL, M.A. 1992. The Bible and Modern Literary Criticism. A Critical Assessment and Annotated Bibliogr aphy. New York, Westport, London : Greenwood Press.

SNYMAN, A.H. 1984. Style and Mcaning in Romans 8:31-9. Neotestamentica, 18:94-103.

VORSTER, J.N. 1991. The Rhetorical Situation of the Letter to the Romans. An Interactional Approach. Pretoria : University of Pretoria. (Unpublished doctoral thesis.)

VOS, C.J.A. 1992. Retoriese seile vir 'n tekstucle skip in homiletiese vaarwaters. Praktiese Teologic in Suid-Afrika, 7:42-56.

WATSON, D.F. 1991. Burton L. Mack. Review: Rhetoric and the New Testament. Biblica, 72:116-119.

WEISS, J. 1897. Bcitrage zur paulinischen Rhetorik. (In Theologische Studien. Professor D. Bernhard Weiss zu seinem 70 . Geburtstage dargebracht. Götlingen : Vandenhoeck \& Ruprecht. p.165247.)

ZERFASS, R. 1987. Grundkurs Predigt 1. Spruchpredigl. Düsseldorf : Patmos Verlag. 
